\title{
Ocean Science During the Corona Virus Pandemic CHALLENGES AND OPPORTUNITIES
}

At the beginning of 2020, the World Health Organization announced the outbreak of a new corona virus-SARS-Cov-2in China. At the time, public health experts issued warnings about the possibility of global pandemic and that the virus that caused the human disease COVID-19 can lead to serious health issues. It was not clear then if the virus outbreak could be contained and remain a regional challenge as similar virus outbreaks during the last decade have suggested. The oceanographic community did not take much note or prepare itself. In late January, I attended the annual meeting of the Partnership for Observation of the Global Ocean (POGO) in Qingdao, China. Many of us left there worried about the local virus situation in China, but not really considering that we all would be in the middle of it six months later. In early February, the three societies that organize the Ocean Sciences Meeting decided to waive the registration fees for attendees from China because the SARS-Cov-2 outbreak was considered a hardship on the participants. However, no measures were taken at the Ocean Sciences Meeting in San Diego to prevent the potential spreading of the virus. Today, we know that the virus was already spreading throughout the US West Coast by then. No reports of virus spreading at the Ocean Sciences Meeting in San Diego reached the organizers. We might have just gotten lucky.

In March, the situation changed rapidly in the Western world. While Asian countries applied their lessons learned during previous virus outbreaks, Europe and North America seemed less concerned and not well prepared. By mid-March, drastic measures such as travel bans and social distancing were implemented. Almost all ocean science was taken "online" and moved to "work from home" operations. Many oceanographic laboratories were closed to visitors, and only essential services were retained. Research vessels around the globe could not exchange crews in foreign ports, and most were called back to their home country base. Dramatic situations emerged, and personal hardships for those at sea and in the field emerged. People spent prolonged times at sea, and return travel options remained uncertain for those far away from home.

With severe restrictions on international travel and stringent health safety measures implemented for seagoing operations, it seemed the tide had turned in favor of robotic systems exploring the ocean. At the end of April, the Global Ocean Observing System (GOOS) community launched a survey on the impacts of the corona pandemic on the global ocean observing system
(Heslop et al., 2020). It became clear that most of the robotic systems used in ocean science need human support from research vessels for deployment and/or servicing equipment. The GOOS survey revealed significant system shortfalls, and further impact is expected as the pandemic prevails. "Despite its significant impacts on the ocean observing system, the COVID-19 crisis can also be an opportunity for us to look at how to build greater resilience into the system," argues Toste Tanhua from GEOMAR, Co-Chair of the Global Ocean Observing System. "The impacts of Covid-19 have brought to light the inter-reliance of systems and some clear weak points that we can now work on to increase system efficiency and robustness."

More recently, epidemiologists and public health experts are suggesting that the corona virus pandemic will be around for quite some time and may only be curtailed by a successful vaccine not yet on the horizon. Thus, complex ocean field campaigns have been delayed for at least one year because crew exchanges in foreign ports are essentially impossible. Moreover, health concerns on research vessels, especially from exchanging scientists, have resulted in scaled back operations. Germany, for example, called all its ocean-going research vessels back home in March, then almost immediately permitted operations with reduced science crews. Single cabin occupancy and quarantine and virus testing upfront are now their standard procedure. For the time being, all expeditions have to start and end in Germany. Similar arrangements are reported for some other countries, but many have canceled all large seagoing expeditions with an unknown restart date. Long-distance operations to the South Atlantic, Pacific, and Indian Oceans have been postponed, and the Antarctic field season has been canceled by most nations.

Despite many hardships and setbacks, there are some noteworthy developments and opportunities. First, addressing the global corona virus pandemic requires global cooperation. The same is true for addressing the downturn of "ocean health" and dealing with climate change or the loss of species and biodiversity. The need to work together is apparent and hopefully brings back more global sharing and collaboration. Second, by necessity, we have to conduct most of our teaching virtually. In-person meetings and science conferences have been postponed or reconfigured to online formats. In principle, these changes should spur more equitable and inclusive participation around the globe, reduce scientific travel, and lead to a reevaluation of the way in which we, as scientists, communicate, collaborate, and engage. 
These challenging times provide a welcome opportunity for reflection. We are rapidly learning new formats to strengthen and even accelerate global engagement in ocean sciences. However, not all sectors of the ocean science community have the same level of access, abilities, choices, and resilience. Those with stable job situations can weather a pandemic more easily than those on short-term contracts. Those who live in parts of the world where the ability to cope with the pandemic is limited, there is no reliable Internet access, and resources are already scarce for conducting ocean science research are seeing their possibilities rapidly declining. A similar level of inequality is found within the research communities. Those who rely on field- or lab-based science are more affected by the pandemic than those who primarily analyze existing data, do theoretical work, or use ocean model simulations. Recent publications show that the pandemic has disproportionately affected women and those from lessprivileged situations (e.g., Myers et al., 2020).

For The Oceanography Society, the pandemic has highlighted the need to reflect on our Society's values. The current, past, and future presidents recently reaffirmed the TOS values (https://tos.org/diversity) and committed to ensure that TOS increases its efforts to address issues such as toxic and non-supportive work climates, the lack of role models, a lack of a sense of belonging, and non-alignment of promotion and tenure incentives with aspirations of women and underrepresented minorities in the ocean sciences around the world. We are about to launch a TOS Justice, Equity, Diversity, and Inclusion Committee to develop actions. At the same time, we are evaluating our Society's financial resilience and exploring new ways to increase and diversify income streams. We welcome any suggestions and opportunities you might want to bring to TOS.

Finally, we are looking forward to the launch of the UN Decade of Ocean Science for Sustainable Development with its mission: "Transformative ocean science solutions for sustainable development, connecting people and our ocean." The future of ocean sciences will be more collaborative, more international, more digital, and more inclusive as we build back from the setback of the pandemic to become more resilient and sustainable.

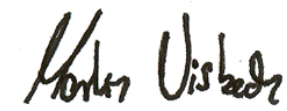

Martin Visbeck, TOS President

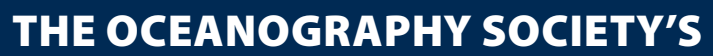
HONORS PROGRAM

One of the most meaningful aspects of being a member of The Oceanography Society (TOS) is the opportunity to recognize and celebrate our colleagues' accomplishments. Please take this opportunity to recognize a colleague, mentor, team, or peer for their exceptional achievements and contributions to the ocean sciences.

\section{DON'T MISS THE \\ NOVEMBER 15, 2020 NOMINATION DEADLINE FOR}

TOS FELLOWS PROGRAM

Recognizing individuals who have attained eminence in oceanography through their outstanding contributions to the field of oceanography or its applications

TOS EARLY CAREER AWARD

For having demonstrated extraordinary scientific excellence and the potential to shape the future of oceanography

TOS MENTORING AWARD

For excellence and/or innovation in mentoring the next generation of ocean scientists

OCEAN OBSERVING TEAM AWARD

Recognizing teams for innovation and excellence in sustained ocean observing for scientific and practical applications

\section{REFERENCES}

Heslop, E., A. Fischer, T. Tanhua, D. Legler, M. Belbeoch, M. Kramp, and V. Lindoso. 2020. Covid-19's impact on the ocean observing system and our ability to forecast weather and predict climate change. Briefing note, Global Ocean Observing System, Intergovernmental Oceanographic Commission of UNESCO, June 29, 2020, https://www.goosocean.org/index. php?option=com_oe\&task=viewDocumentRecord\&doclD=26920.

Myers, K.R., W.Y. Tham, Y. Yin, N. Cohodes, J.G. Thursby, M.C. Thursby, P. Schiffer, J.T. Walsh, K.R. Lakhani, and D. Wang. 2020. Unequal effects of the COVID-19 pandemic on scientists. Nature Human Behaviour, https://doi.org/10.1038/ s41562-020-0921-y. 